\title{
NO FURY LIKE A WOMAN COLD-CALLED
}

\author{
A degree of foresight.
}

\section{BY JEREMY R. BUTLER}

"Hello?"
"Hello, Mrs Cooper?"
"Yes?"
"This is Flip Figglesworth with Cassandra
Mutual."
"Sorry, we are long-time customers of -"
"Dutch Consolidated. But did you know
that Cassandra is not your ordinary insur-
ance firm? We employ the world's most accu-
rate precognitive actuaries - bypassing the
unnecessary risk-taking that plagues the aver-
age insurer lets us pass the savings on to you."
"Precognitive actuaries. Seers?"
"Yes, maam. Best in the world."
"Isn't that illegal?"
"Not with the passage of Bill 413. Perhaps we could set up a time to sit down with your husband and discuss -

"Tony's far too busy for that."

"Then might I interest you in flood protection at 35\% of what you're currently paying?"

"Um, maybe."

"What about fire protection at $40 \%$ off?"

"That's good! How about car insurance?"

"For you or your husband?"

"For me."

"I can save you \$100 a month."

"And my husband?"

"Well, there are other factors than price that you should consider. For instance -"

"Just tell me the price."

"I'm afraid it would be more expensive."

"How much more expensive?"

"Considerably."

"Why is that?"

"Under Bill 413 I cannot disclose - "

"You're saying he'll have another accident, aren't you? A bad one?"

"I'm afraid I -"

"Oh no. What about life insurance for him?"

"No problem there. Just a fraction of what you're currently paying."

"Phew, that's great. For a moment there, I thought... I thought he might die."

"Well, we all do. Just please remember to read the fine print in all the policies."

"What are you saying?"

"Nothing. It's just you should read our policies closely to ensure they meet your needs."

"Any fine print in particular?"

"Well ... denial of payment to beneficiaries in cases of domestic homicide, for example."

"I'm sorry, did you say homicide?"

"No, well, yes, but no. That's just an example. Read the fine print, that's all I'm saying."

"What the..."
"How about travel insurance? Kazakhstan is host to many infectious diseases. Our hospitalization and repatriation policies - "

"Kazakhstan? I don't travel anywhere we don't have an embassy."

"No, of course not. My mistake. Can I interest you in -"

"Wait."

"- dental _"

"Are you saying what I think you're saying?"

"That there's no bad time for dental?"

"No. That my husband will be killed, intentionally, in his car? By me?"

"Under Bill 413, I can neither confirm nor deny -"

"Why would I do that? That's not like me. I do yoga. I mean, I've thought about it, who hasn't? But running away to a country I know nothing about? That sounds ... reckless."

"I hear it has great food."

"Really?"

"If you like spicy."

"I love spicy. Regardless, I'm not going to kill my husband."

"I'm glad to hear that. Maybe there's a time when the three of us could sit down. What about tomorrow night?"

"No, he's at a meeting."

"Thursday?"

"Charity benefit."

"Next week?"

"Conference."

"Oh."

“Tony's a busy man.”

"I see."

"I'm sure you do."

"I'm just a salesman, ma’am. I only know what the computer tells me, like his frequent travel policies with a Ms Tanya Riggins."

"His secretary."

"I see."

"Stop that."

“Oh, no, I didn't mean to suggest ... I’m sorry if I -"

"Don't be sorry, Mr Figglesworth. You've helped me immensely. I've been in denial $\rightarrow$ NATURE.COM

Follow Futures: y @NatureFutures

f go.nature.com/mtoodm about long-term planning. I'm going to revamp our entire portfolio. Not only that, I'm going to spread the word to my friends and family and give them your name."

"Fantastic! I would greatly appreciate that. To be honest, I haven't been meeting my targets and the boss says -"

"When I'm done you'll ride the leader board for the rest of the year. I just need a few more quotes."

"Certainly!"

"A life-insurance policy for Tanya Riggins, payable to her husband, Jim. Would that be more or less expensive than her current one?"

"Considerably more, I'm afraid."

"Uh huh. I thought so. Anyone else that I shouldn't recommend to you?"

"Like acquaintances whose rates would go up significantly?"

"Right, I wouldn't want to drown out the praises everyone will be singing ..."

"Good idea. Sally Forthright."

"Sally! OK, I’ll just scratch her off."

"Connie Gardner."

"Gotcha. She's gone."

"Patty St James."

"My maid of honour!?!"

"Yes. And please, don't mention fire coverage to her."

"Fire. Understood. Anyone else?"

"Oh, quite a few more. At least two dozen."

"Aaaargh!"

"I mean, no, under Bill 413 I can neither -"

"OK, I just need one last quote."

"Fine."

"A life-insurance policy for me."

"Beneficiary?"

"You."

"Me? We haven't even - "

"How much?"

"Well, it's quite unusual, but not unethical, I suppose. The premiums would be quite low."

"That's fantastic. I'm so glad. Thank you."

"You're welcome. I will print up the policies and perhaps I could come by this evening for your signature?"

"..."

"Hello? Mrs Cooper? Hello? Oh, Figglesworth, you idiot! Not again." -

Jeremy R. Butler is a psychiatrist, part-time improviser and father to two energetic girls. 